\title{
Diacylglycerol activates the influx of extracellular cations in T-lymphocytes independently of intracellular calcium-store depletion and possibly involving endogenous TRPG gene products
}

\author{
Alessandra GAMBERUCCI*, Emanuele GIURISATO*, Paola PIZZO†, Maristella TASSI*, Roberta GIUNTI*, \\ Deirdre Patricia MCINTOSH* and Angelo BENEDETTI*1 \\ *Dipartimento di Fisiopatologia e Medicina Sperimentale, Università di Siena, Viale A. Moro no. 1, 53100-Siena, Italy, and †Dipartimento di Scienze Biomediche \\ Sperimentali, Università di Padova, 35121-Padova, Italy
}

In Jurkat and human peripheral blood T-lymphocytes, 1-oleoyl2-acetyl-sn-glycerol (OAG), a membrane-permeant analogue of diacylglycerol, activated the influx of $\mathrm{Ca}^{2+}, \mathrm{Ba}^{2+}$ and $\mathrm{Sr}^{2+}$. OAG also caused plasma-membrane depolarization in $\mathrm{Ca}^{2+}$-free media that was recovered by the addition of bivalent cation, indicating the activation of $\mathrm{Na}^{+}$influx. OAG-induced cation influx was (i) mimicked by the natural dacylglycerol 1-stearoyl-2-arachidonyl$s n$-glycerol, (ii) not blocked by inhibiting protein kinase $\mathrm{C}$ or in the absence of phopholipase $\mathrm{C}$ activity and (iii) blocked by $\mathrm{La}^{3+}$ and $\mathrm{Gd}^{3+}$. Differently from OAG, both thapsigargin and phytohaemagglutinin activated a potent influx of $\mathrm{Ca}^{2+}$, but little influx of $\mathrm{Ba}^{2+}$ and $\mathrm{Sr}^{2+}$. Moreover, the influx of $\mathrm{Ca}^{2+}$ activated by thapsigargin and that activated by $\mathrm{OAG}$ were additive. Furthermore, several drugs (i.e. econazole, SKF96365, carbonyl cyanide $p$-trifluoromethoxyphenylhydrazone, 2-aminoethoxy diphenylborate and calyculin-A), while inhibiting the influx of
$\mathrm{Ca}^{2+}$ induced by both thapsigargin and phytohaemagglutinin, did not affect OAG-stimulated cation influx. Transient receptor potential (TRP) 3 and TRP6 proteins have been shown previously to be activated by diacylglycerol when expressed heterologously in animal cells [Hofmann, Obukhov, Schaefer, Harteneck, Gudermann and Schultz (1999) Nature (London) 397, 259-263]. In both Jurkat and peripheral blood T-lymphocytes, mRNA encoding TRP proteins 1, 3, 4 and 6 was detected by reverse transcriptase PCR, and the TRP6 protein was detected by Western blotting in a purified plasma-membrane fraction. We conclude that T-cells express a diacylglycerol-activated cation channel, unrelated to the channel involved in capacitative $\mathrm{Ca}^{2+}$ entry, and associated with the expression of TRP6 protein.

Key words: 2-aminoethoxydiphenyl borate, capacitative calcium entry, phytohaemagglutinin, T-cell receptor, thapsigargin.

\section{INTRODUCTION}

Engagement of many cell-surface receptors by agonists leads to sustained elevations or long-lasting oscillatory changes in the cytosolic free calcium concentration $\left(\left[\mathrm{Ca}^{2+}\right]_{\mathrm{i}}\right)$. An increase in $\left[\mathrm{Ca}^{2+}\right]_{\mathrm{i}}$ occurs primarily because of $\mathrm{Ca}^{2+}$ release from $\operatorname{Ins}(1,4,5) P_{3}$ sensitive intracellular pools and is generally accompanied by an influx of extracellular $\mathrm{Ca}^{2+}$ ions. This influx can be mediated by various (often putative) $\mathrm{Ca}^{2+}$ channels located on the plasma membrane (PM), such as receptor-operated, second-messengeractivated or store-operated $\mathrm{Ca}^{2+}$ channels $[1,2]$. The storeoperated $\mathrm{Ca}^{2+}$ influx, originally termed capacitative $\mathrm{Ca}^{2+}$ entry (CCE) [3], is controlled by the filling state of intracellular $\mathrm{Ca}^{2+}$ pools located in the endoplasmic reticulum [4].

Channels, messengers and mechanisms involved in CCE have been investigated extensively in the last decade. Electrophysiological studies suggest that $\mathrm{CCE}$ depends on the activation of a highly selective $\mathrm{Ca}^{2+}$-release-activated $\mathrm{Ca}^{2+}$ current $\left(\mathrm{I}_{\mathrm{CRAC}}\right)$, at least in mast cells [5] and T-lymphocytes [6], and channels/ currents with similar characteristics have been described in other cell types [7].

Searching for the molecular identity of the channels involved in CCE, attention has been focused in the last few years on mammalian homologues of the Drosophila transient receptor potential (TRP) and TRP-like ion channels (see [8] for a review). At least seven mammalian genes, designated $T R P 1-7$, have been cloned [8]. Expression of these genes in various cell lines, however, has resulted in varying patterns of response, including spontaneous activity (e.g. [9,10]), augmentation of CCE (e.g. [11,12]), apparent direct activation by receptor occupancy (e.g. [13]), activation by mechano-osmotic stimuli [14] and activation by diacylglycerol (DAG) and DAG analogues [15-18].

In particular, human TRP6 and TRP3 channels heterologously overexpressed in host cell lines have been reported to be activated by DAG and DAG analogues in a membrane-delimited protein kinase $\mathrm{C}$-independent manner [15]. These observations suggest that certain TRP channels may be activated directly by DAG formed upon agonist stimulation of phospholipase $\mathrm{C}$. Consistent with this possibility, it has been shown that the DAG membranepermeant analogue 1-oleoyl-2-acetyl-sn-glycerol (OAG) can activate the $\alpha 1$-adrenoceptor-activated $\mathrm{Ca}^{2+}$-permeable cation channel of rabbit portal vein smooth muscle [19]. Recently it has been also observed that $\mathrm{OAG}$ can activate a non-specific cation current in T-lymphocytes [20]. While this work was being

Abbreviations used: $\left[\mathrm{Ca}^{2+}\right]_{i}$, cytosolic free calcium concentration; PM, plasma membrane; CCE, capacitative Ca ${ }^{2+}$ entry; I $\mathrm{CRAC}$, Ca ${ }^{2+}$-releaseactivated $\mathrm{Ca}^{2+}$ current; TRP, transient receptor potential; DAG, diacylglycerol; OAG, 1-oleoyl-2-acetyl-sn-glycerol; SAG, 1-stearoyl-2-arachidonyl-snglycerol; RT-PCR, reverse transcriptase PCR; PHA, phytohaemagglutinin; FCCP, carbonyl cyanide p-trifluoromethoxyphenylhydrazone; bis-oxonol, bis-(1,3-diethylthiobarbituric acid) trimethine oxonol; 2-APB, 2-aminoethoxydiphenyl borate; fura 2/AM, fura 2 acetoxymethyl ester.

To whom correspondence should be addressed (e-mail benedetti@unisi.it). 
completed, evidence was provided for the activation by OAG of a non-specific cation channel that correlates with the expression of TRP6 in the adrenal chromaffin cell line PC12 [21].

Here we have characterized in human Jurkat and peripheral blood T-lymphocytes the effect of DAG on $\mathrm{Ca}^{2+} /$ cation influx, as well as the expression of various TRP genes [by reverse transcriptase PCR (RT-PCR)] and some of their products (by Western blotting). The results indicate that T-cells possess a cation-influx pathway activated by DAG, which is unrelated to CCE and correlated with the presence of endogenous TRP6 proteins in the PM.

\section{MATERIALS AND METHODS}

\section{Materials}

OAG, 1-stearoyl-2-arachidonyl-sn-glycerol (SAG), thapsigargin, staurosporine, phytohaemagglutinin (PHA), PMA, U73122, ouabain, econazole, carbonyl cyanide $p$-trifluoromethoxyphenylhydrazone (FCCP), alamethicin and sulphinpyrazone were obtained from Sigma (St. Louis, MO, U.S.A.). Fura 2 acetoxymethyl ester (fura 2/AM) and bis-(1,3-diethylthiobarbituric acid) trimethine oxonol (bis-oxonol) were from Molecular Probes (Eugene, OR, U.S.A.). SKF96365, calyculin-A and 2-aminoethoxydiphenyl borate (2-APB) were from Calbiochem-Novabiochem (La Jolla, CA, U.S.A.). Calmidazolium was from Boehringer Roche Diagnostics (Indianapolis, IN, U.S.A.). Nalco 1060 colloidal silica was obtained from Nalco Chemical Co. (Chicago, IL, U.S.A.). Polyacrylic acid (99000 Da) was from Aldrich Chemical Co. (Milwaukee, WI, U.S.A.). All other chemicals were of analytical grade.

\section{Cells}

Jurkat cells (supplied kindly by Dr Tullio Pozzan, Università di Padova, Padova, Italy) and Jurkat-derived JCaM 1.6 cells (purchased from the A.T.C.C., Rockville, MD, U.S.A.) were grown in RPMI 1640 (Gibco/BRL, Grand Island, NY, U.S.A.) supplemented with heat-inactivated $10 \%$ foetal calf serum (Gibco/BRL), $2 \mathrm{mM}$ L-glutamine, 100 units/ml penicillin and $100 \mu \mathrm{g} / \mathrm{ml}$ streptomycin (Sigma). Cells, harvested $48-60 \mathrm{~h}$ after transplantation, were washed and resuspended $\left(2 \times 10^{6} / \mathrm{ml}\right)$ in $\mathrm{NaCl}$ /Hepes medium (140 mM NaCl, $5.4 \mathrm{mM} \mathrm{KCl}, 1 \mathrm{mM}$ $\mathrm{MgCl}_{2}, 1 \mathrm{mM} \mathrm{CaCl}_{2}, 10 \mathrm{mM}$ glucose and $15 \mathrm{mM}$ Hepes, $\mathrm{pH}$ 7.4). Cell suspensions were kept at room temperature and used within $1 \mathrm{~h}$ for subsequent assays.

Human peripheral blood T-lymphocytes were prepared according to [22]. Briefly, fresh mononuclear leucocytes were prepared by Ficoll-Paque density centrifugation from buffy coats of peripheral blood from healthy donors, and cultured in RPMI 1640 supplemented with $10 \%$ foetal calf serum, $2 \mathrm{mM}$ L-glutamine, penicillin and streptomycin. T-lymphocyte lines were selected by adding $1 \mu \mathrm{g} / \mathrm{ml}$ PHA to the culture medium and then maintained in the presence of 100 units $/ \mathrm{ml}$ interleukin-2 from culture day 3 onwards. T-lymphocytes were used from culture day 10 to 20 .

\section{Measurement of $\mathrm{Ca}^{2+}, \mathrm{Ba}^{2+}$ and $\mathrm{Sr}^{2+}$ influx}

The influx of $\mathrm{Ca}^{2+}$ to cells was measured using the intracellular fluorescent indicator fura 2 to measure changes in the cytoplasmic concentration of the cation. Cells were loaded with $3 \mu \mathrm{M}$ fura 2/AM for $20 \mathrm{~min}$ at $37^{\circ} \mathrm{C}$ according to standard procedures [23]. After loading, the cells were kept at room temperature in $\mathrm{NaCl} / \mathrm{Hepes}$ medium until use. Just before the experiment, a $1 \mathrm{ml}$ aliquot of the cell suspension (approx. $4 \times 10^{6}$ cells) was rapidly centrifuged and resuspended in $2 \mathrm{ml}$ of fresh medium. Where indicated in the individual experiments, the resuspension medium contained no added $\mathrm{CaCl}_{2}$. Fluorescence was measured with a Perkin-Elmer LS-3B fluorimeter (excitation and emission wavelengths, 340 and $509 \mathrm{~nm}$ respectively) equipped with magnetic stirring and temperature control. To minimize leakage of trapped fura 2 , the temperature was reduced to $30^{\circ} \mathrm{C}$ and $200 \mu \mathrm{M}$ sulphinpyrazone was included in the medium [24]. The results were not affected by sulphinpyrazone. At the end of each incubation, digitonin $(50 \mu \mathrm{g} / \mathrm{ml})$ and EGTA $(20 \mathrm{mM})$ were added in order to measure maximal $\left(F_{\max }\right)$ and minimal $\left(F_{\min }\right)$ fluorescence values. Fluorescence $\mathrm{mV}$ output signals were acquired at $0.25 \mathrm{~s}$ intervals using MacLab ${ }^{\circledR}$ hardware (AD Instruments), equipped with Chart version 3.2.5 software. The $K_{\mathrm{d}}$ value for the $\mathrm{Ca}^{2+}$-fura 2 complex was assumed to be $185 \mathrm{nM}$ at $30^{\circ} \mathrm{C}$ [25]. Values of $\left[\mathrm{Ca}^{2+}\right]_{\mathrm{i}}$ were calculated by using CA Cricket Graph III software according to the formula: $\left[\mathrm{Ca}^{2+}\right]_{\mathrm{i}}=K_{\mathrm{d}}\left[\left(F-F_{\text {min }}\right) /\right.$ $\left.\left(F_{\max }-F\right)\right]$. In most experiments fluorescence was measured with only one excitation wavelength as described above. Control experiments were also conducted by point measurement of the ratio of fura 2 fluorescence ( $509 \mathrm{~nm}$ emission wavelength) with excitation at 340 and $380 \mathrm{~nm}$; the $\left[\mathrm{Ca}^{2+}\right]_{i}$ values obtained were fully consistent with those obtained by continuously monitoring fluorescence with excitation fixed at $340 \mathrm{~nm}$ as described above. In parallel samples to which no fura 2/AM was added, it was verified that all the treatments employed caused only minor variations in cell autofluorescence.

The influx of $\mathrm{Ba}^{2+}$ and $\mathrm{Sr}^{2+}$ was evaluated in fura 2-loaded cells by measuring the fluorescence of the intracellular $\mathrm{Ba}^{2+}-/ \mathrm{Sr}^{2+}$ fura 2 complexes (excitation and emission wavelengths were 340 and $509 \mathrm{~nm}$ respectively) as described for $\left[\mathrm{Ca}^{2+}\right]_{\mathrm{i}}$ measurement, except that $\left[\mathrm{Ba}^{2+}\right]_{i}$ and $\left[\mathrm{Sr}^{2+}\right]_{i}$ were expressed as ratio values according to the formula: $\left[\mathrm{Ba}^{2+}\right]_{\mathrm{i}}$ or $\left[\mathrm{Sr}^{2+}\right]_{\mathrm{i}}=\left(F-F_{\min }\right) /$ $\left(F_{\max }-F\right)$.

\section{Measurement of PM potential}

PM potential was measured with the potential-sensitive fluorescent dye bis-oxonol essentially as described in [26]. Briefly, a sample of the cell suspension $\left(2 \times 10^{6} / \mathrm{ml}\right)$ was incubated in $\mathrm{NaCl} / \mathrm{Hepes}$ medium containing $150 \mathrm{nM}$ bis-oxonol until the fluorescence reached a steady state. After completion of the experiment, the signal was calibrated with $20 \mu \mathrm{g} / \mathrm{ml}$ alamethicin, which caused complete depolarization. Excitation and emission wavelengths were 540 and $580 \mathrm{~nm}$ respectively.

\section{RT-PCR analysis of mRNA transcripts of TRP genes}

RT-PCR analysis was performed as reported in [7]. Briefly, total mRNA was isolated from Jurkat and peripheral blood Tlymphocytes $\left[(1-1.5) \times 10^{7}\right.$ cells $]$ using the Oligotex Direct mRNA kit (Qiagen, Valencia, CA, U.S.A.). RNA concentration and quality were checked by spectrometry and electrophoresis on $1 \%$ agarose/formamide gels. mRNA (100 ng) was reversetranscribed and PCR amplification was carried out using the Access RT-PCR System (Promega, Madison, WI, U.S.A.). Amplification (35 cycles) was carried out on a Biometra TRIOThermoblock using 25 pmol of each specific primer for six different TRP genes (TRP1-6) [27] and for the housekeeping genes glyceraldehyde-3-phosphate dehydrogenase $(G 3 P D H)$ and $\beta$-actin as internal controls.

The primers used were as follows: TRP1 forward, 5'-GATTTTGGGAAATTTCTAGGAATG-3'; TRP1 reverse, 5'-CTCATGATTTGCTATCAGCTGG-3'; TRP2 forward, 5'-CGTTCCAGTTTCTCTTCTGGACCAT-3'; TRP2 reverse, 5'-AGCAT- 

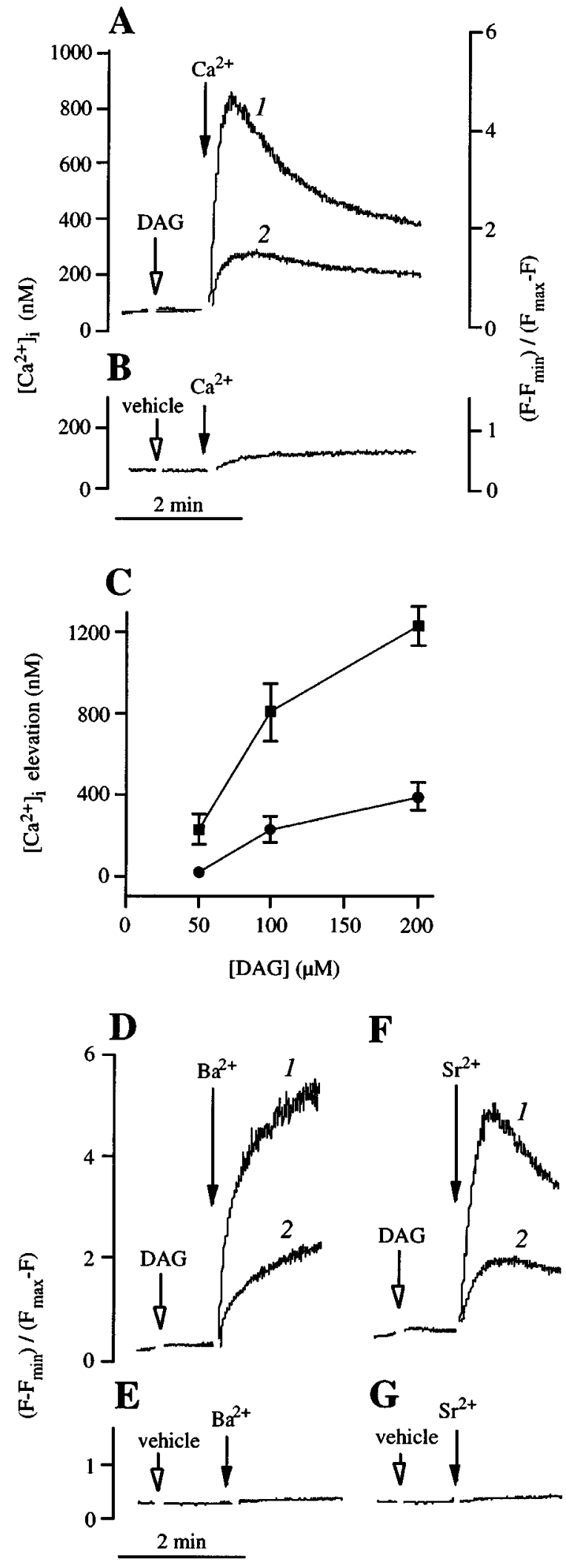

Figure 1 DAGs activate the influx of $\mathrm{Ca}^{2+}(\mathrm{A}$ and $\mathrm{C}), \mathrm{Ba}^{2+}(\mathrm{D})$ and $\mathrm{Sr}^{2+}(\mathrm{F})$ in Jurkat T-lymphocytes

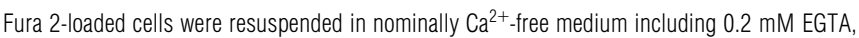
and $\mathrm{CaCl}_{2}, \mathrm{BaCl}_{2}$ or $\mathrm{SrCl}_{2}(1.2 \mathrm{mM}$ each) were added (black arrows) to the incubation system. (A) DAG addition (empty arrow) was $100 \mu \mathrm{M} \mathrm{OAG} \mathrm{to} \mathrm{trace} 1$ and $100 \mu \mathrm{M}$ SAG to trace 2. (B) Control for (A): vehicle only (ethanol) was added. (C) $\mathrm{Ca}^{2+}$ influx as a function of DAG
CGTCCTCGATCTTCTGG-3'; TRP3 forward, 5'-GTGGACTACATGGGCCAGAACGC-3'; TRP3 reverse, 5'-AGTCCCTTGTAGGCATTGATCCT-3'; TRP4 forward, 5'-TCTGCAGATATCTCTGGGAAGGATGC-3'; TRP4 reverse, 5'-AAGCTTTGTTCGAGCAAATTTCCATTC-3'; TRP5 forward, 5'-CCCGGCATGAATTCACGGAG-3'; TRP5 reverse, 5'-CATGGTCGGCAATGAGCTGGTAG-3'; TRP6 forward, 5'-GAGAACATAGGCTATGTTCTGTATGGAGTC-3'; TRP6 reverse, 5'-GCCATCATCCTCAATTTCCTGG-3'; $G 3 P D H$ forward, $5^{\prime}$ ACCACAGTCCATGCCATCAC-3'; G3PDH reverse, 5'-TCCACCACCCTGTTGCTGTA- $3^{\prime} ; \beta$-actin forward, $5^{\prime}$-TTGTAACCAACTGGGACGATATG- $3^{\prime} ; \beta$-actin reverse, $5^{\prime}$-GATCTTGATCTTCATGGTGCTAGG-3'. The PCR product $(5 \mu \mathrm{l})$ was analysed on $2 \%$ agarose gels. Identities of the amplified cDNA fragments were confirmed by sequence analysis.

\section{Preparation of PM fractions}

A subcellular fraction highly enriched in PMs was prepared from Jurkat and peripheral blood human T-lymphocytes essentially as reported in [28]. Briefly, PMs were coated with positively charged silica particles by treating cells with $1 \%$ colloidal silica in Mesbuffered saline (125 mM NaCl$/ 20 \mathrm{mM} \mathrm{Mes,} \mathrm{pH}$ 6.5) for $5 \mathrm{~min}$ at $10-12{ }^{\circ} \mathrm{C}$. Cells were washed with Mes-buffered saline, and then treated with $1 \%$ sodium polyacrylate in Mes-buffered saline to cross-link and shield PM-bound silica. After removal of excess polyacrylate, cells were lysed by nitrogen cavitation [28], and silica-coated large open sheets of PM were isolated by centrifugation on a Nycodenz (Gibco) gradient as detailed in [29]. PM pellets were resuspended in Mes-buffered saline and again centrifuged on a Nycodenz gradient. The degree of purity of the PM fraction was evaluated by Western-blot analysis of the Tlymphocyte PM-associated proteins CD3- $\epsilon$ subunit, CD45 and GTP-binding protein $\beta$ subunit, as well as of the endoplasmic reticulum protein type 2 CaATPase. Between 80 and $90 \%$ of the $\mathrm{PM}$ proteins and virtually no endoplasmic reticulum CaATPase protein were recovered in the PM fraction, as compared with a crude cell lysate. No detectable amounts of cytochrome $c$ oxidase activity (as a mitochondrial marker enzyme) were present in the PM fraction.

\section{Western-blot analysis of proteins encoded by TRP1, 3, 4 and 6 genes}

PM fractions and crude cell lysates were processed for electrophoresis and immunoblotted according to standard methodology. Protein size markers at 160, 105, 75, 50 and $35 \mathrm{kDa}$ were used to determine the apparent molecular mass of immunoblotted proteins. Immunoblots were probed with the different antibodies recognizing the TRP1, 3, 4 and 6 proteins (Alomone Labs, Jerusalem, Israel). The immunoreactive proteins were visualized using a horseradish peroxidase-conjugated anti-mouse monoclonal antibody and enhanced chemiluminescence reagents (Amersham Biosciences, Piscataway, NJ, U.S.A.). Parallel samples were probed with different anti-TRP antibodies blocked

concentration:

OAG:

SAG. Maximal $\left[\mathrm{Ca}^{2+}\right]_{\mathrm{i}}$ peak increase over the basal $\left[\mathrm{Ca}^{2+}\right]_{\mathrm{i}}$ level after $\mathrm{Ca}^{2+}$ addition was measured from traces obtained as shown in (A). Data are means \pm S.E.M., $n=4-9$. (D) and (F) DAG addition (empty arrows) was $100 \mu \mathrm{M}$ OAG to trace 1 and $100 \mu \mathrm{M}$ SAG to trace 2. (E) and (G) Controls for $(\mathbf{D})$ and $(\mathbf{F})$ respectively: vehicle only (ethanol) was added. Values are expressed in $(\mathbf{A})$ and $(\mathbf{B})$ as calibrated $\left[\mathrm{Ca}^{2+}\right]_{\mathrm{i}}$ (left-hand side) and fura 2 fluorescence ratio $\left(F-F_{\min }\right) /\left(F_{\max }-F\right)$ (right-hand side); in (D-G) as fluorescence ratio $\left(F-F_{\min }\right) /\left(F_{\max }-F\right)$. These and the following fura 2 experiments are representative of 3-12 different trials. 
previously by pre-incubation with the corresponding antigen peptides.

\section{RESULTS}

\section{Activation of cation influx by DAG}

To demonstrate activation of $\mathrm{Ca}^{2+}$ influx by $\mathrm{DAG}$, cells were challenged with the membrane-permeant analogue OAG [15] or a naturally occurring DAG (i.e. SAG) in nominally $\mathrm{Ca}^{2+}$-free solutions including EGTA $(0.2 \mathrm{mM})$, and $\mathrm{Ca}^{2+}$ entry was initiated by elevation of extracellular $\mathrm{Ca}^{2+}$ to $1 \mathrm{mM}$. Both $\mathrm{OAG}$ and $\mathrm{SAG}$ caused rapid elevations of $\left[\mathrm{Ca}^{2+}\right]_{i}$ in Jurkat cells (Figure 1A). In $\mathrm{Ca}^{2+}$-free medium (Figure 1A), $\left[\mathrm{Ca}^{2+}\right]_{\mathrm{i}}$ did not change following OAG or SAG addition, which indicates the absence of $\mathrm{Ca}^{2+}$ mobilization from intracellular stores. Both the extent (Figure 1C) and rate (results not shown) of $\mathrm{Ca}^{2+}$ influx were a function of the concentration of OAG and SAG. The DAG membranepermeant analogue appeared to be at least three times more active than the naturally occurring acylglycerol (Figure 1C). Influx of the $\mathrm{Ca}^{2+}$ surrogate cations $\mathrm{Ba}^{2+}$ and $\mathrm{Sr}^{2+}$ was then evaluated using the same protocol. As shown in Figures 1(D) and $1(\mathrm{~F})$, both OAG and SAG also promoted the influx of extracellular $\mathrm{Ba}^{2+}$ and $\mathrm{Sr}^{2+}$. Again, $\mathrm{OAG}$ was more active than SAG.

Additional experiments showed that exogenously added DAG can activate bivalent cation influx not only in Jurkat cells, but also in human peripheral blood T-lymphocytes. As shown in Figure 2, OAG and SAG activated $\mathrm{Ca}^{2+}$ and $\mathrm{Ba}^{2+}$ influx in peripheral blood T-lymphocytes, although the activation appeared to be relatively less that in Jurkat T-cells.

Both $\mathrm{La}^{3+}$ and $\mathrm{Gd}^{3+}(2 \mu \mathrm{M}$ each) blocked OAG-induced cation influx in Jurkat as well in peripheral blood T-lymphocytes (results not shown). These cations, although non-specific channel blockers, should hardly act on non-specific alterations of PM

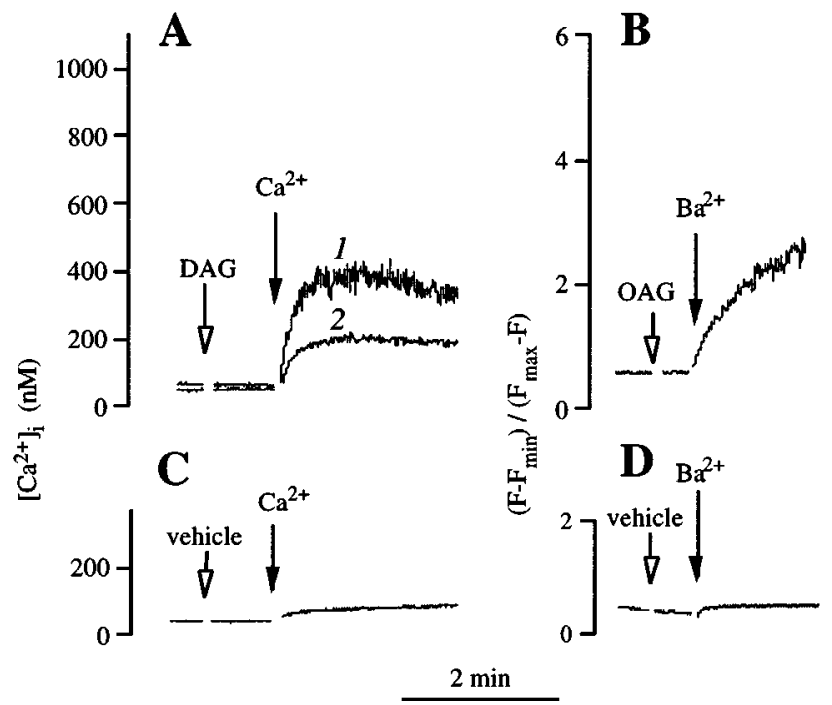

Figure 2 DAGs activate the influx of (A) $\mathrm{Ca}^{2+}$ and (B) $\mathrm{Ba}^{2+}$ in human peripheral blood T-lymphocytes

Fura 2-loaded cells were resuspended in nominally $\mathrm{Ca}^{2+}$-free medium including $0.2 \mathrm{mM} \mathrm{EGTA}$, and $\mathrm{CaCl}_{2}$ or $\mathrm{BaCl}_{2}$ (1.2 $\mathrm{mM}$ each) were added (black arrows) to the incubation system. (A) DAG addition (empty arrow) is $100 \mu \mathrm{M} \mathrm{OAG}$ to trace 1 and $100 \mu \mathrm{M} \mathrm{SAG}$ to trace 2. (B) Addition (empty arrow) is $100 \mu \mathrm{M}$ OAG. (C) and (D) Controls for (A) and (B), respectively: vehicle only (ethanol) was added.
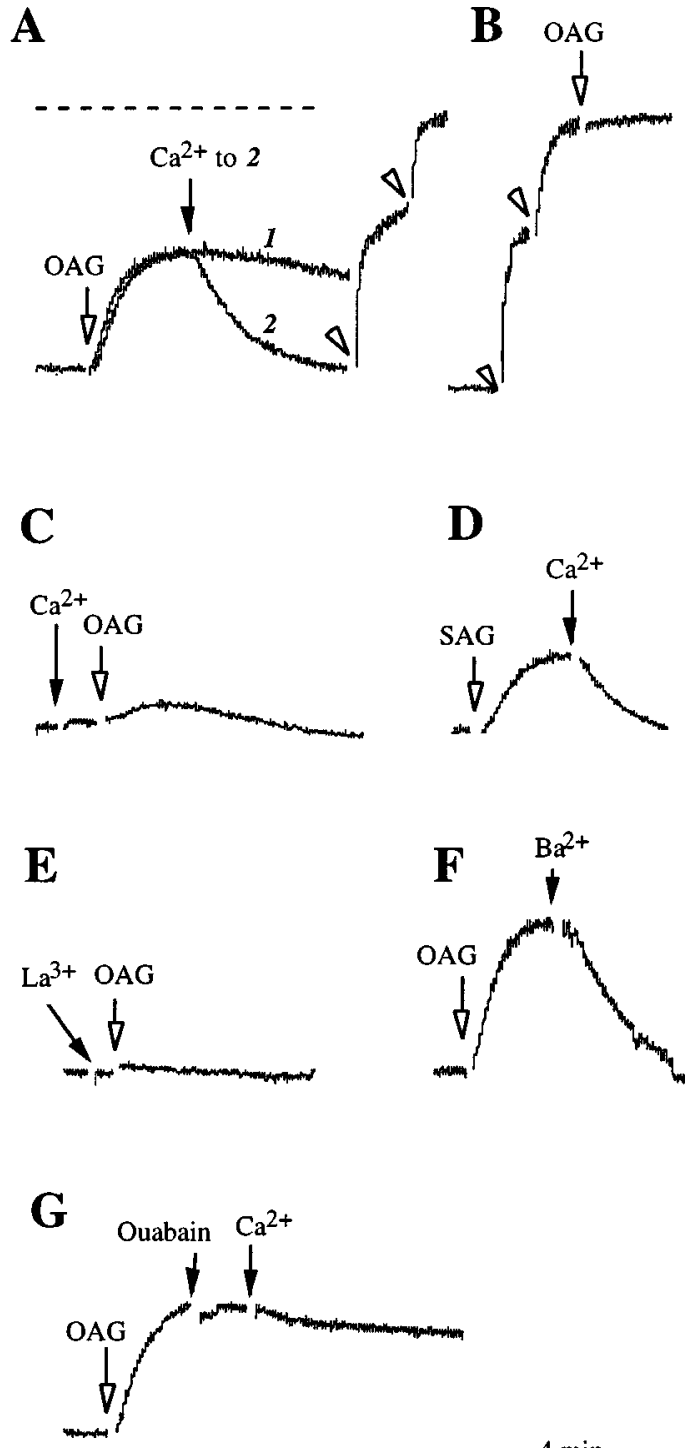

$4 \mathrm{~min}$

Figure 3 Effect of DAGs on PM potential in Jurkat T-lymphocytes

Jurkat cells were resuspended $\left(2 \times 10^{6}\right.$ cells $\left./ \mathrm{ml}\right)$ in nominally $\mathrm{Ca}^{2+}$-free medium without EGTA, and PM potential was evaluated with the fluorescent probe bis-oxonol as detailed in the Materials and methods section. (A) OAG-induced PM depolarization in $\mathrm{Ca}^{2+}$-free medium and recovery of $\mathrm{PM}$ potential after $\mathrm{Ca}^{2+}$ addition. Additions were: $100 \mu \mathrm{M} \mathrm{OAG}, 1.5 \mathrm{mM} \mathrm{CaCl}_{2}$ to trace 2, and two additions of $10 \mu \mathrm{g} / \mathrm{ml}$ alamethicin (arrowheads); the dotted line represents the fluorescence value for the maximal depolarization as measured in cells resuspended in a medium with $\mathrm{KCl}$ substituted for by $\mathrm{NaCl}$. (B) OAG does not change the fluorescent signal in cells fully depolarized by alamethicin; additions were $2 \times 10 \mu \mathrm{g} / \mathrm{ml}$ alamethicin (arrowheads) and $100 \mu \mathrm{M}$ OAG. (C) OAG causes little depolarization in the presence of extracellular $\mathrm{Ca}^{2+}$; additions were $1.5 \mathrm{mM} \mathrm{CaCl}$, and $100 \mu \mathrm{M}$ OAG. (D) SAG-induced PM depolarization in $\mathrm{Ca}^{2+}$-free medium and recovery of PM potential after $\mathrm{Ca}^{2+}$ addition; additions were $100 \mu \mathrm{M}$ SAG and $1.5 \mathrm{mM} \mathrm{CaCl}_{2}$. (E) $\mathrm{La}^{3+}$ blocks OAG-induced PM depolarization; additions were $2 \mu \mathrm{M} \mathrm{LaCl}_{3}$ and $100 \mu \mathrm{M}$ OAG. (F) $\mathrm{Ba}^{2+}$ reverses OAG-induced PM depolarization; additions were $100 \mu \mathrm{M} \mathrm{OAG}$ and $1.5 \mathrm{mM} \mathrm{BaCl}_{2}$. (G) Ouabain prevents recovery by $\mathrm{Ca}^{2+}$ of OAG-induced depolarization; additions were $100 \mu \mathrm{M} \mathrm{OAG}, 1 \mathrm{mM}$ ouabain and $1.5 \mathrm{mM} \mathrm{CaCl}_{2}$.

permeability, which indicates that DAG must act on PM cation channels.

DAG is a well-known activator of protein kinase C. To evaluate the possible role of protein kinase $\mathrm{C}$ in the activation of $\mathrm{Ca}^{2+}$ influx by DAG, Jurkat cells were cultured in the presence of $2 \mu \mathrm{M}$ PMA for $40 \mathrm{~h}$ or treated with the inhibitor staurosporine 

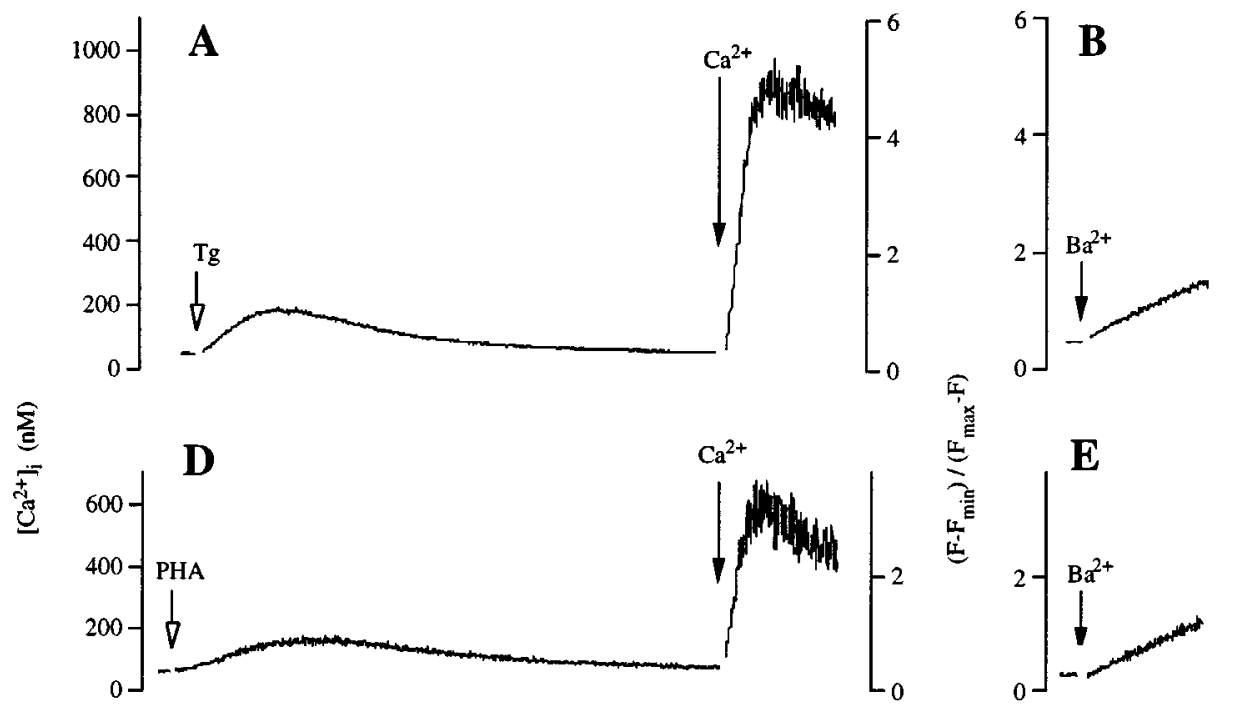

C
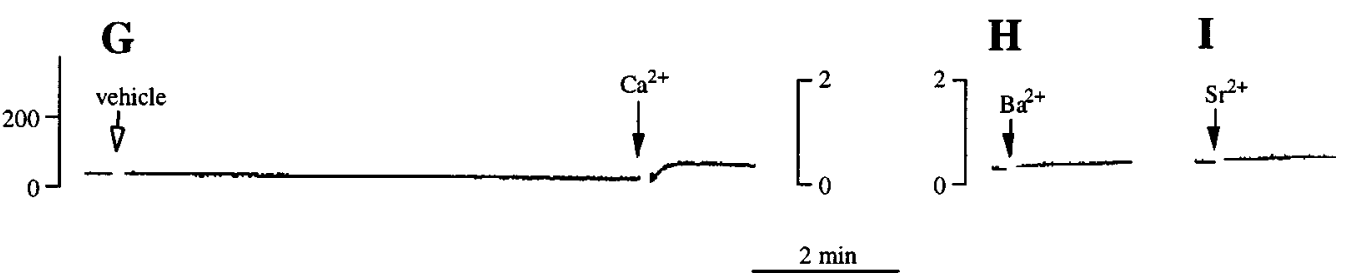

\section{Figure 4 Influx of $\mathrm{Ca}^{2+}, \mathrm{Ba}^{2+}$ and $\mathrm{Sr}^{2+}$ activated by thapsigargin (A-C) and $\mathrm{PHA}(\mathrm{D}-\mathrm{F})$ in Jurkat T-lymphocytes}

Fura 2-loaded cells were resuspended in nominally $\mathrm{Ca}^{2+}$-free medium including $0.2 \mathrm{mM} \mathrm{EGTA}$, and $\mathrm{CaCl}_{2}, \mathrm{BaCl}_{2}$ or $\mathrm{SrCl}_{2}$ (1.2 $\mathrm{mM}$ each) were added (black arrows) to the incubation system. (A) Thapsigargin $(\mathrm{Tg} ; 0.2 \mu \mathrm{M})$ was added when indicated. (B) and $(\mathbf{C})$ Thapsigargin $(0.2 \mu \mathrm{M})$ was added 7 min before the addition of $\mathrm{Ba}^{2+}$ and $\mathrm{Sr}^{2+}$ respectively. (D) $\mathrm{PHA}^{2}\left(7 \mu \mathrm{g} / \mathrm{ml}^{2}\right)$ was added when indicated. (E) and $(\mathbf{F})$ PHA $(7 \mu \mathrm{g} / \mathrm{ml})$ was added 7 min before the addition of $\mathrm{Ba}^{2+}$ and $\mathrm{Sr}^{2+}$ respectively. (G-I) Controls; vehicle only (DMSO) was added. Values are expressed as follows: $(\mathbf{A}),(\mathbf{D})$ and $(\mathbf{G})$ as calibrated $\left[\mathrm{Ca}^{2+}\right]_{i}$ (left-hand side) and fura 2 fluorescence ratio $\left(F-F_{\min }\right) /\left(F_{\max }-F\right)$ (right-hand side); (B), (C), (E), (F), (H) and $(\mathbf{I})$ as the fluorescence ratio $\left(F-F_{\min }\right) /\left(F_{\max }-F\right)$.

$(1 \mu \mathrm{M})$ for 20 min. Treatment with PMA has been used to downregulate protein kinase $\mathrm{C}$ isoforms in TRP6-expressing Chinese hamster ovary $\mathrm{K} 1$ cells by Hofmann et al. [15], and has been shown to largely reduce the expression of protein kinase $\mathrm{C} \beta 1$ in Jurkat cells [30]. This isoform is involved in Jurkat cell $\mathrm{Ca}^{2+}$ signalling [30]. OAG-induced $\mathrm{Ca}^{2+}$ influx was unaffected by both the afore-mentioned treatments (results not shown).

The effect of DAG was also independent of the T-cell-receptor signalling pathways and phospholipase $\mathrm{C}$ activity. In fact, $\mathrm{OAG}$ also promoted the influx of $\mathrm{Ca}^{2+}$ in the Jurkat-derived cell line JCaM 1.6 (results not shown). This cell line lacks the activity of p56 Lck tyrosine kinase, which is crucial for the $\mathrm{Ca}^{2+}$-signalling events following surface-receptor stimulation of Jurkat T-cells [31]. Moreover, treatment of Jurkat cells with the phospholipase $\mathrm{C}$ inhibitor $\mathrm{U} 73122(2.5 \mu \mathrm{M})$ for $10 \mathrm{~min}$ did not affect the OAGinduced influx of $\mathrm{Ca}^{2+}$ (results not shown). In control experiments (results not shown) we verified that T-cell-receptor-dependent $\mathrm{Ca}^{2+}$ signalling was absent from both the JCaM 1.6 cell line and the U73122-pre-treated Jurkat cells. PHA $(7 \mu \mathrm{g} / \mathrm{ml})$ in fact did not cause any change in $\left[\mathrm{Ca}^{2+}\right]_{\mathrm{i}}$, although it was active under control conditions.

It has been shown that heterologously overexpressed DAGsensitive TRP channels are also permeable to univalent cations such as $\mathrm{Na}^{+}$[15], particularly in $\mathrm{Ca}^{2+}$-free medium. The possibility that DAG also promotes the influx of $\mathrm{Na}^{+}$was evaluated in Jurkat T-lymphocytes with the membrane-potential-sensitive dye bis-oxonol. Should DAG promote $\mathrm{Na}^{+}$influx, this would result in a decrease in PM potential. The addition of OAG or SAG depolarized Jurkat T-cells maintained in the nominally $\mathrm{Ca}^{2+}$-free medium (Figures 3A and 3D), whereas a little depolarization was evident in $\mathrm{Ca}^{2+}$-containing media (Figure 3C). The DAG-induced loss in membrane potential was almost completely recovered after calcium re-admission to $\mathrm{Ca}^{2+}$-free systems (Figures $3 \mathrm{~A}$ and 3D). The possibility that the DAGs simply interfere with the fluorimetric assay of PM potential was ruled out by the following control experiments. (i) OAG did not substantially affect the fluorescent signal in cells that had already been depolarized by pre-treating them with alamethicin (Figure 3B). (ii) No change in bis-oxonol fluorescence was evident upon $\mathrm{OAG}$ addition to cells pre-treated with $2 \mu \mathrm{M} \mathrm{LaCl}$ (Figure $3 \mathrm{E}$ ), a condition that resulted in the complete inhibition of OAG-induced $\mathrm{Ca}^{2+}$ influx (see above).

The reversal of OAG-induced cell depolarization by $\mathrm{Ca}^{2+}$ may be due to at least two components: a preferential influx of $\mathrm{Ca}^{2+}$ instead of $\mathrm{Na}^{+}$through the same PM-entry pathway, and/or the activation of $\mathrm{PM} \mathrm{Ca}{ }^{2+}$-activated $\mathrm{K}^{+}$channels. These channels have been reported to be expressed in T-lymphocytes [32]. The former component, however, appears to be the major one, on the basis of the following results: (i) the $\mathrm{Ca}^{2+}$-induced recovery of membrane depolarization was blocked by the $\mathrm{Na}^{+} / \mathrm{K}^{+}$ATPase inhibitor ouabain (Figure 3G); (ii) inhibitors of the $\mathrm{Ca}^{2+}$ activated $\mathrm{K}^{+}$channels (i.e. apamin and tetra-ethylammonium cloride) were ineffective (results not shown); and (iii) bivalent cations other than $\mathrm{Ca}^{2+}$, i.e. $\mathrm{Ba}^{2+}$ and $\mathrm{Sr}^{2+}$, also reversed the 


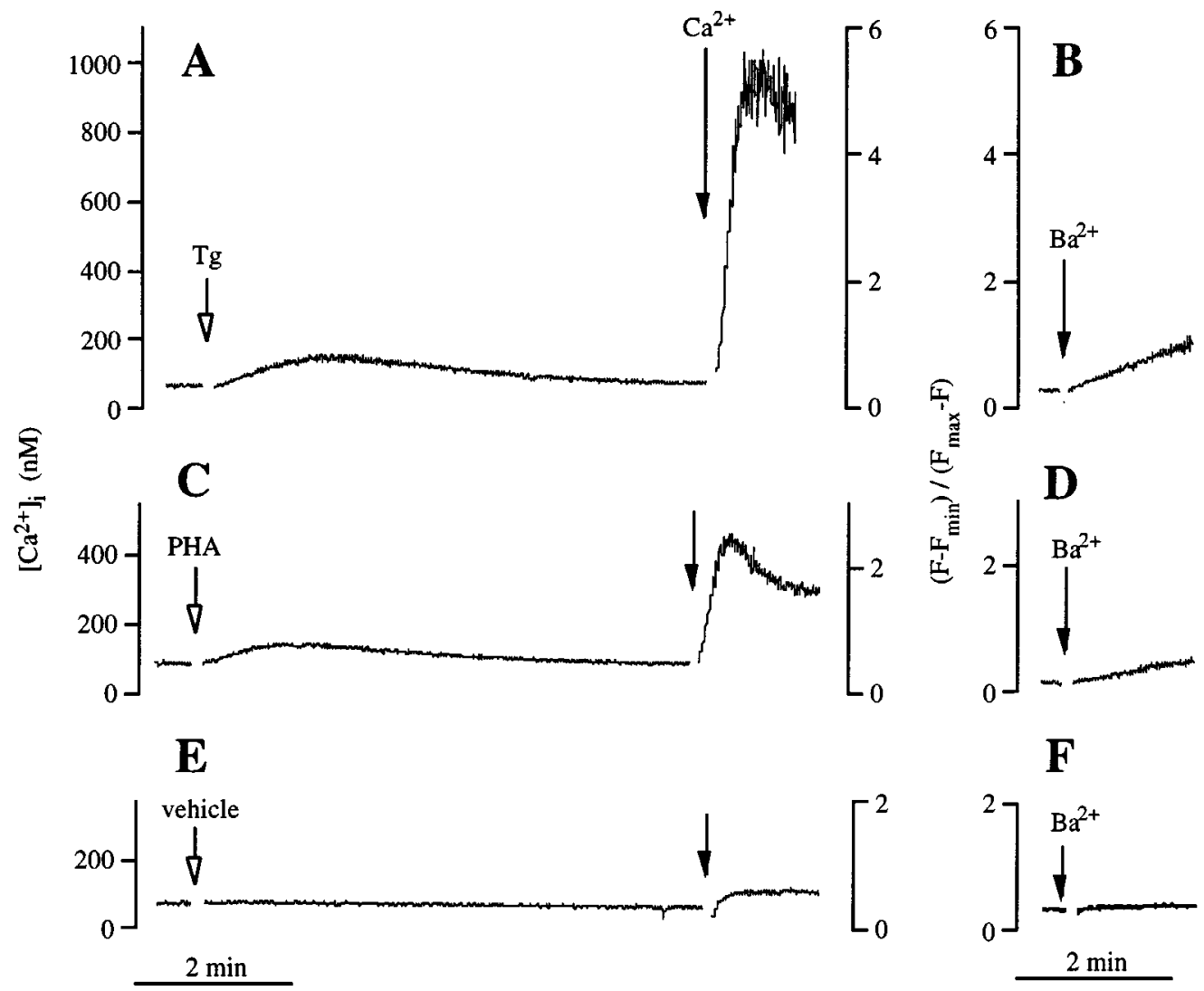

Figure 5 Influx of $\mathrm{Ca}^{2+}$ and $\mathrm{Ba}^{2+}$ activated by thapsigargin (A, B) and PHA (C, D) in peripheral blood T-lymphocytes

Fura 2-loaded cells were resuspended in nominally $\mathrm{Ca}^{2+}$-free medium including $0.2 \mathrm{mM} \mathrm{EGTA}$, and $\mathrm{CaCl}_{2}$ or $\mathrm{BaCl}_{2}(1.2 \mathrm{mM}$ each) were added (black arrows) to the incubation system. (A) Thapsigargin (Tg: $0.2 \mu \mathrm{M}$ ) was added when indicated. (B) Thapsigargin $(0.2 \mu \mathrm{M})$ was added 7 min before $\mathrm{Ba}^{2+}$ addition. (C) PHA $(7 \mu \mathrm{g} / \mathrm{ml})$ was added when indicated. (D) PHA (7 $\left.\mu \mathrm{g} / \mathrm{ml}\right)$ was added 7 min before $\mathrm{Ba}^{2+}$ addition. $(\mathbf{E})$ and $(\mathbf{F})$ Controls; vehicle only (DMSO) was added. Values are expressed as: $(\mathbf{A}),(\mathbf{C})$ and $(\mathbf{E})$ calibrated $\left[\mathrm{Ca}^{2+}\right]_{\mathrm{i}}$ (left-hand side) and fura 2 fluorescence ratio $\left(F-F_{\min }\right) /\left(F_{\max }-F\right)$ (right-hand side); (B), (D) and $(\mathbf{F})$ the fluorescence ratio $\left(F-F_{\min }\right) /\left(F_{\max }-F\right)$.

OAG-induced cell depolarization (see Figure $3 \mathrm{~F}$ for the effect of $\mathrm{Ba}^{2+}$ ), despite the fact that they are poor activators (or even inhibitors, e.g. $\mathrm{Ba}^{2+}$; [33]) of $\mathrm{Ca}^{2+}$-activated $\mathrm{K}^{+}$channels.

\section{Cation selectivity of the channels activated by $O A G$, thapsigargin and PHA}

We compared the influx of cations induced by the store-depleting agent thapsigargin and the T-cell agonist PHA with that induced by OAG. Cells were treated with thapsigargin or PHA in a nominally $\mathrm{Ca}^{2+}$-free medium, and cation influx was activated by the addition of $1 \mathrm{mM} \mathrm{Ca}{ }^{2+}, \mathrm{Ba}^{2+}$ or $\mathrm{Sr}^{2+}$. In Jurkat T-lymphocytes, in the cases of both thapsigargin and PHA stimulation, the pattern of cation influx was different from that observed in OAG-stimulated cells (compare the results in Figure 4 with those in Figure 1). In particular, both thapsigargin and PHA promoted a large influx of $\mathrm{Ca}^{2+}$ and a relatively small influx of the $\mathrm{Ca}^{2+}$ surrogate cations $\mathrm{Ba}^{2+}$ and $\mathrm{Sr}^{2+}$. This is consistent with a relatively high selectivity for $\mathrm{Ca}^{2+}$ of the channels involved in CCE [34]. On the other hand, the OAG-responsive TRP channels heterologously expressed in host cells have been reported to possess a poor selectivity for bivalent cations [15]. Similar results were obtained in peripheral blood T-lymphocytes (Figure 5). Again, thapsigargin and PHA appeared to activate a cation-influx pathway that was highly selective for $\mathrm{Ca}^{2+}$ with respect to $\mathrm{Ba}^{2+}$

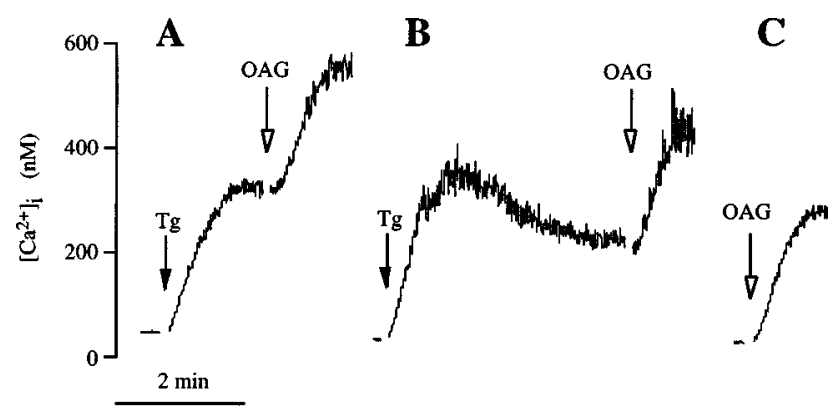

Figure $6 \mathrm{OAG}$ induces the influx of $\mathrm{Ca}^{2+}$ in Jurkat T-lymphocytes pretreated with thapsigargin

Fura 2-loaded cells (see the Materials and methods section) were resuspended in a medium containing $0.2 \mathrm{mM}$ added $\mathrm{Ca}^{2+}$ and treated with thapsigargin $(\mathrm{Tg} ; 0.5 \mu \mathrm{M})$ and/or $100 \mu \mathrm{M}$ OAG where indicated.

ions, differently from the cation influx activated by $\mathrm{OAG}$ (compare Figure 5 with Figure 2).

Additional experiments (Figure 6) revealed that thapsigargininduced $\mathrm{CCE}$ and OAG-stimulated $\mathrm{Ca}^{2+}$ influx were additive. In these experiments cells were treated with a supramaximal dose of thapsigargin $(0.5 \mu \mathrm{M})$ and then treated with OAG. In addition, 


\section{Table 1 Effect of various treatments and inhibitors on OAG-, thapsigargin- and PHA-induced influx of $\mathrm{Ca}^{2+}$ and $\mathrm{Ba}^{2+}$}

$\mathrm{Ca}^{2+}$ and $\mathrm{Ba}^{2+}$ influx was measured after the respective addition of $\mathrm{Ca}^{2+}$ or $\mathrm{Ba}^{2+}(1 \mathrm{mM})$ to cells treated with $100 \mu \mathrm{M} \mathrm{OAG}$ for $1 \mathrm{~min}, 0.1 \mu \mathrm{M}$ thapsigargin for $6 \mathrm{~min}$ or $7 \mu \mathrm{g} / \mathrm{ml} \mathrm{PHA}$ for 7 min in $\mathrm{Ca}^{2+}$-free medium. Values for $\mathrm{Ca}^{2+}$ influx are expressed as increases in $\left[\mathrm{Ca}^{2+}\right]_{\mathrm{i}}(\mathrm{nM})$ following $\mathrm{Ca}^{2+}$ addition. Values for $\mathrm{Ba}^{2+}$ influx were expressed as increases in the fura 2 fluorescence ratio $\left(F-F_{\min }\right) /\left(F_{\max }-F\right)$ at 1 min following $\mathrm{Ba}^{2+}$ addition (see Figures $1,2,6$ and 7$)$. Econazole $(15 \mu \mathrm{M})$, SKF96365 (30 $\left.\mu \mathrm{M}\right)$ and 2 -APB $(75 \mu \mathrm{M})$ were added to cells 1 min prior to adding $\mathrm{Ca}^{2+}$ or $\mathrm{Ba}^{2+}$. Cells were treated with $1 \mu \mathrm{M}$ FCCP for 12 min prior to adding $\mathrm{Ca}^{2+}$ or $\mathrm{Ba}^{2+}$ [36]. Calmidazolium (10 $\left.\mu \mathrm{M}\right)$ and calyculin-A (100 $\mathrm{nM}$ ) were added to cells 6 and 12 min prior to adding $\mathrm{Ca}^{2+}$ or $\mathrm{Ba}^{2+}$, respectively. Data are the means \pm S.D. from three to five, or the mean from two, separate experiments.

\begin{tabular}{|c|c|c|c|c|c|c|c|}
\hline \multirow[b]{3}{*}{ Inhibitor } & \multirow{3}{*}{ Treatment ... } & \multicolumn{6}{|c|}{$\mathrm{Ca}^{2+}$ or $\mathrm{Ba}^{2+}$ influx } \\
\hline & & \multicolumn{2}{|l|}{$O A G$} & \multicolumn{2}{|c|}{ Thapsigargin } & \multicolumn{2}{|l|}{ PHA } \\
\hline & & $\mathrm{Ca}^{2+}$ & $\mathrm{Ba}^{2+}$ & $\mathrm{Ca}^{2+}$ & $\mathrm{Ba}^{2+}$ & $\mathrm{Ca}^{2+}$ & $\mathrm{Ba}^{2+}$ \\
\hline \multicolumn{8}{|c|}{ Jurkat T-lymphocytes } \\
\hline None & & $806 \pm 144$ & $4.8 \pm 0.3$ & $930 \pm 160$ & $0.62 \pm 11$ & $570 \pm 95$ & $0.53 \pm 0.12$ \\
\hline Econazole & & $830 \pm 122$ & $5.0 \pm 0.5$ & $74 \pm 10$ & $0^{\star}$ & $33 \pm 0.2$ & $0^{*}$ \\
\hline SKF96365 & & $812^{-}$ & $5.3^{-}$ & $67^{-}$ & - & $30^{-}$ & - \\
\hline $2-A P B$ & & $782 \pm 10$ & 5.5 & $38 \pm 8$ & - & 29 & - \\
\hline FCCP & & $1100 \pm 230$ & - & $40 \pm 7$ & $0^{*}$ & $28 \pm 5$ & $0^{*}$ \\
\hline Calmidazolium & & $790 \pm 110$ & - & $150 \pm 24$ & - & $130 \pm 22$ & - \\
\hline Calyculin-A & & $671 \pm 119$ & - & $58 \pm 6$ & - & $30 \pm 5$ & - \\
\hline \multicolumn{8}{|c|}{ Peripheral T-Iymphocytes } \\
\hline None & & $298 \pm 53$ & 1.6 & $864 \pm 214$ & $0.50 \pm 13$ & $296 \pm 78$ & $0.32 \pm 0.12$ \\
\hline Econazole & & 280 & - & $73 \pm 18$ & $0^{*}$ & 28 & $0^{*}$ \\
\hline 2-APB & & 311 & - & 51 & - & 27 & - \\
\hline
\end{tabular}

* No increase in fura 2 fluorescence was measurable.

the cells were treated in medium containing a low concentration of $\mathrm{Ca}^{2+}(0.2 \mathrm{mM})$ in order to keep the thapsigargin-induced increase in $\left[\mathrm{Ca}^{2+}\right]_{\mathrm{i}}$ relatively low and therefore to make evident a further increase in $\left[\mathrm{Ca}^{2+}\right]_{i}$ caused by the subsequent $\mathrm{OAG}$ stimulation. Under these experimental conditions, the complete discharge of endoplasmic reticulum $\mathrm{Ca}^{2+}$ stores by thapsigargin caused a sustained $\left[\mathrm{Ca}^{2+}\right]_{i}$ increase (see Figure $6 \mathrm{~B}$ ), most probably due to CCE. The addition of OAG in this phase resulted in a further $\left[\mathrm{Ca}^{2+}\right]_{i}$ increase (Figures 6A and 6B), which was very similar to that observed upon addition of $\mathrm{OAG}$ to control cells (Figure 6C).

\section{Pharmacological inhibition of cation influxes activated by $O A G$, thapsigargin and PHA}

The effect of various drugs on thapsigargin-, PHA- and OAGinduced influx of $\mathrm{Ca}^{2+}$ and $\mathrm{Ba}^{2+}$ ions is summarized in Table 1 . The CCE inhibitors econazole and SKF96365 [35,36] did not modify the influx of $\mathrm{Ca}^{2+}$ and $\mathrm{Ba}^{2+}$ induced by OAG, in both Jurkat and peripheral blood T-lymphocytes (Table 1). On the other hand, these drugs largely inhibited the influx of $\mathrm{Ca}^{2+}$ and $\mathrm{Ba}^{2+}$ induced by the treatment of cells with both thapsigargin and PHA (Table 1).

The drug 2-APB was used originally as an $\operatorname{Ins} P_{3}$-receptor blocker [16]. Subsequently, 2-APB has also been shown [37] to block thapsigargin-induced $\mathrm{CCE}$ and receptor-induced storeindependent activation of TRP3 channels overexpressed in host cells. This drug, however, did not inhibit the direct activation of overexpressed TRP3 channels by OAG [16,37]. As shown in Table 1, 2-APB potently inhibited the influx of $\mathrm{Ca}^{2+}$, promoted by either thapsigargin or PHA, in both Jurkat and peripheral blood T-lymphocytes. On the other hand, 2-APB was fully inactive with respect to $\mathrm{OAG}$-induced $\mathrm{Ca}^{2+}$ influx in both cell types.

It has been observed previously that the mitochondrial uncoupler FCCP inhibits CCE [38]. This effect is likely to be due to the decrease in cell ATP levels [38]. FCCP might also reduce the ability of mitochondria to take up $\mathrm{Ca}^{2+}$, which may then increase feedback inhibition of CCE [39]. The pre-treatment of Jurkat cells with FCCP almost completely blocked thapsigargin-induced $\mathrm{CCE}$ and PHA-induced $\mathrm{Ca}^{2+}$ influx, but did not affect the OAGinduced influx of $\mathrm{Ca}^{2+}$ (Table 1). After the treatment with this mitochondrial poison the extent of $\mathrm{Ca}^{2+}$ influx promoted by OAG appeared even larger (Table 1).

The calmodulin inhibitor calmidazolium was ineffective on OAG-induced calcium influx but largely reduced thapsigargininduced CCE (Table 1). This drug has been reported to activate basal activity of TRP3 channels in unstimulated cells overexpressing this TRP isoform, probably by counteracting an inhibitory effect of calmodulin [40]. However, we observed that calmidazolium treatment did not promote any basal influx of $\mathrm{Ca}^{2+}$ and $\mathrm{Ba}^{2+}$ in unstimulated Jurkat cells (results not shown).

It has been shown that calyculin-A inhibits the activation of CCE by phospholipase $\mathrm{C}$-dependent agonists and thapsigargin [41], but not the direct activation by OAG of TRP3 channels overexpressed in host cells [16]. As reported in Table 1, pretreating Jurkat T-cells with calyculin-A almost completely blocked both thapsigargin- and PHA-stimulated $\mathrm{Ca}^{2+}$ influx, but did not affect the influx of $\mathrm{Ca}^{2+}$ activated by OAG addition.

\section{Expression of different TRP genes and their products in Jurkat cells and peripheral blood T-lymphocytes}

We probed for the presence of mRNA transcripts of the TRPI-6 genes in both Jurkat and peripheral blood T-lymphocytes by RT-PCR. As shown in Figure 7, transcripts of TRP1, 3, 4 and 6 were present in both Jurkat and circulating T-lymphocytes, whereas little or no mRNA transcripts of the TRP2 and 5 genes were detected.

Western-blot analysis did not reveal any immunoreactive band corresponding to, or close to, the expected size for TRP1, 3 and 4 proteins in a purified PM fraction prepared from Jurkat and peripheral T-lymphocytes, whereas bands of the expected sizes were revealed in brain microsomes, at approx. 90, 100 and $95 \mathrm{kDa}$, in the case of the anti-TRP1, 3 and 4 antibodies, respectively (results not shown). 


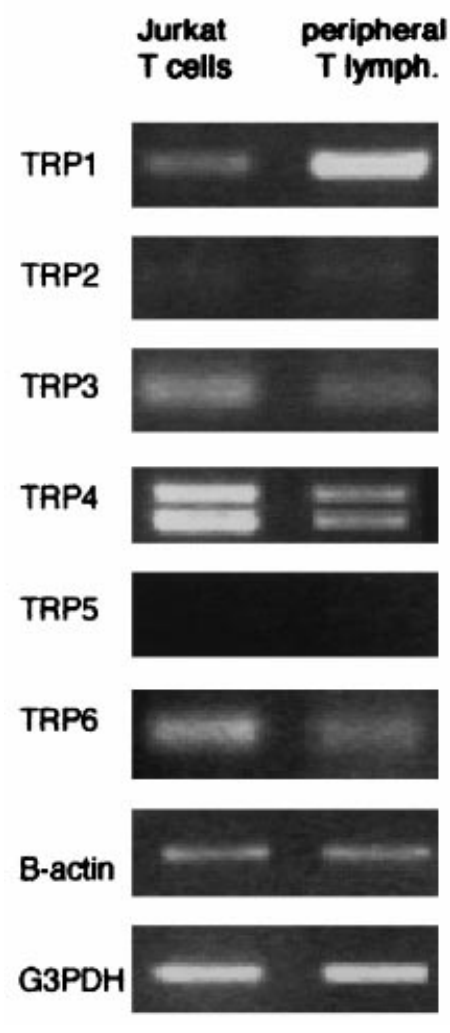

Bp

365

193

Figure 7 RT-PCR analysis of different TRP genes in Jurkat and peripheral blood T-lymphocytes

RT-PCRs (35 cycles) were carried out from total mRNA of cultured Jurkat cells and human peripheral blood T-lymphocytes [(1-1.5) $\times 10^{7}$ cells] using specific primers for TRP1-6, and for the housekeeping genes $\beta$-actin and G3PDH as internal controls (see the Materials and methods section). The product $(5 \mu \mathrm{l})$ was analysed by $2 \%$ agarose gel. Gels were stained with ethidium bromide. The sizes of the amplified cDNA fragments are indicated (in bp).

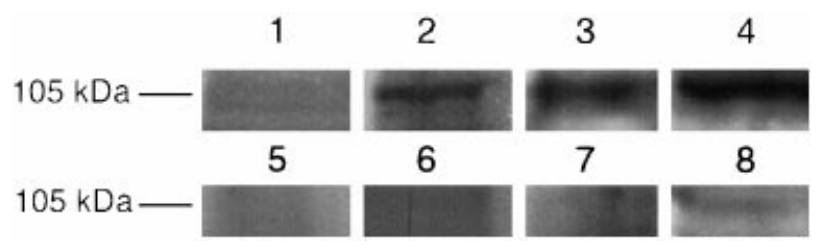

Figure 8 Detection of the TRP6 protein in a PM fraction from Jurkat and peripheral blood T-lymphocytes by Western-blot analysis

A purified PM fraction and total cell membranes were prepared, subjected to SDS/PAGE and immunoblotted with an anti-TRP6 antibody as detailed in the Materials and methods section. Lane 1, total membranes from Jurkat cells (50 $\mu \mathrm{g}$ of protein); lane 2, PM from Jurkat cells (50 $\mu \mathrm{g}$ of protein); lane 3 , PM from peripheral blood T-lymphocytes (50 $\mu \mathrm{g}$ of protein); lane 4 , rat brain membranes (10 $\mu \mathrm{g}$ of protein) as a positive control. Lanes $5-8$ are the same as lanes $1-4$, respectively, except that the anti-TRP6 antibody was preincubated with the antigenic peptide to assess the specificity of the immunoreaction. The positions of the 105-kDa protein size marker are indicated.

On the other hand, antibodies against TRP6 revealed an immunoreactive protein with an apparent size of $105 \mathrm{kDa}$ in a purified PM fraction of Jurkat and peripheral T-lymphocytes (Figure 8, lanes 2 and 3). The immunoreactive band was undetectable in a crude fraction containing total cell membranes of Jurkat (Figure 8, lane 1) and peripheral T-lymphocytes (results not shown), probably because of a low percentage of the antigens in total cell membranes. An immunoreactive band at $105 \mathrm{kDa}$ was also present in rat brain membranes (Figure 8, lane 4; see also [18]). The intensity of the $105 \mathrm{kDa}$ band was largely reduced by probing the blots with antibody preincubated with the antigen peptide (Figure 8, lanes 5-8), indicating a specific immunoreaction.

\section{DISCUSSION}

The results obtained with a naturally occurring DAG (SAG) and with the membrane-permeant DAG analogue OAG show that human T-lymphocytes possess an endogenous cation influx pathway/channel that can be activated by DAG. The DAG-activated channels appear to be non-specific in that they allow not only the influx of $\mathrm{Ca}^{2+}$, but also, to a comparable extent, the influx of the surrogate cations $\mathrm{Ba}^{2+}$ and $\mathrm{Sr}^{2+}$. Moreover, we provide evidence for the influx of the univalent cation $\mathrm{Na}^{+}$in the absence of extracellular $\mathrm{Ca}^{2+}$, by evaluating cell-membrane potential. The effect of DAG appears to be direct and membranedelimited, since inhibitors of protein kinase $\mathrm{C}$ and cell treatments suitable for virtually abolishing the activity of this kinase do not affect the DAG-induced cation influx.

These features of the putative DAG-sensitive channels of Tlymphocytes are consistent with those reported for human TRP3 and human TRP6 channels overexpressed in Chinese hamster ovary K1 cells [15]. This suggests that TRP3/6 channels endogenously expressed in T-lymphocytes may mediate the cation influx activated by DAG. Consistent with this possibility, both the mRNA transcript and evidence for the expression of a TRP6 protein were found in Jurkat and peripheral blood lymphocytes. In fact, we observed a protein with an apparent molecular mass of $105 \mathrm{kDa}$ in a highly purified PM preparation of these cells. The $105 \mathrm{kDa}$ band was also present in brain microsomes that we assumed to be a bona fide positive control for the expression of endogenous TRP6 protein (see [18]). Moreover, the size of the immunoreactive protein $(105 \mathrm{kDa})$ matches that of the TRP6A isoform of TRP6 expressed in COS cells (107 kDa) [18]. Consistent with this, here we have used antibodies against the $\mathrm{N}$ terminally located amino acid sequence 24-38 of the TRP6 protein, which should selectively detect TRP6A. This isoform, in fact, possesses a 54-amino-acid sequence (including our epitope) at the N-terminus, which is absent in the TRP6B and C isoforms [18]. This N-terminal domain has been shown to be crucial for activation by OAG [18]. At variance with our results, the DAGstimulated cation influx very recently described by Tesfai et al. [21] in the adrenal chromaffin cell line PC12 was associated with expression of the TRP6B isoform. Importantly, we immunorevealed the TRP6 protein in a highly purified PM preparation, as expected for a channel that mediates extracellular $\mathrm{Ca}^{2+} /$ cation influx.

The results obtained using RT-PCR show that mRNAs encoding TRP proteins 1, 3 and 4 were also expressed in Jurkat and blood T-lymphocytes. However, no immunoreactive bands for TRP1, 3 and 4 were revealed. It is possible that the amount of expressed protein of these TRP isoforms is too low to be revealed by Western blotting. Moreover, the levels of mRNA may not correlate with those of the corresponding expressed proteins. Relatively low amounts of TRP3 channels might at least contribute to DAG-induced cation influx in lymphocytes. However, previous evidence in cells heterologously expressing TRP3 channels militates against this possibility. First, SKF96365 has been shown to block the basal activity of TRP3 channels [13], whereas we observed that this drug does not modify DAGinduced cation influx. Secondly, it has been reported that 
calmidazolium activates TRP3, probably by removing a constitutive inhibition of calmodulin towards this channel [40]; we observed instead that calmidazolium does not activate any basal cation influx in T-lymphocytes (A. Gamberucci, E. Giurisato and A. Benedetti, unpublished work). Heterologously expressed TRP7 can be also activated by DAG [17]. We have not investigated the expression of this TRP isoform, and its possible participation in DAG-activated $\mathrm{Ca}^{2+}$ influx cannot be excluded.

The present data indicate that the DAG-activated channels are different from those responsible for CCE. First, activation of CCE by depleting endoplasmic reticulum $\mathrm{Ca}^{2+}$ stores with thapsigargin results in a highly selective influx of $\mathrm{Ca}^{2+}$, and in little influx of $\mathrm{Ba}^{2+}$ and $\mathrm{Sr}^{2+}$. Secondly, a variety of inhibitors blocks thapsigargin-induced $\mathrm{CCE}$, but not OAG-induced cation influx. Thirdly, OAG causes a further increase in $\mathrm{Ca}^{2+}$ influx in the presence of maximal activation of CCE by thapsigargin. It has been suggested very recently [20] that a DAG-activated nonselective cation current, other than $\mathrm{I}_{\mathrm{CRAC}}$, is somehow involved in $\mathrm{I}_{\mathrm{CRAC}}$ activation and in the CCE process in T-lymphocytes. However, the latter speculation is based on indirect electrophysiological evidence in Jurkat T-cells. The authors of [20] reported that a putative calcium-influx factor (prepared from cells whose reticular $\mathrm{Ca}^{2+}$ stores had been depleted) activates not only the classic $\mathrm{I}_{\mathrm{CRAC}}$ but also a non-selective cation current, which can also be activated by OAG in a non-additive manner. Whatever the difference between the present experimental conditions and those of [20], we observed clearly that thapsigargin, PHA and the T-cell-receptor-stimulatory antibodies OKT3 and TR66 (A. Gamberucci, E. Giurisato and A. Benedetti, unpublished work) cannot activate a cation-influx pathway with properties similar to those of the OAG-stimulated one.

The fact that even a maximal stimulation of the T-cell receptor by PHA or stimulatory antibodies does not appear to involve any DAG-sensitive cation influx raises the question of the role played by DAG-sensitive (TRP6?) cation channels in T-lymphocyte signalling. Studies with heterologously overexpressed TRP6 channels indicate that phospholipase $\mathrm{C}$-dependent agonists activate the channel, probably in a DAG-dependent manner $[15,18]$. Under these experimental conditions, however, the number of channel units is presumably much higher that in the case of endogenous channels. Moreover, whereas the overexpression of a channel-protein subunit probably results in the formation of homomeric channels, the native channels may be constituted by different protein subunits, and have different properties [9]. Previous studies with cells possessing endogenous DAGsensitive cation channels gave opposite results. Transfection of rabbit portal vein myocytes with TRP6 antisense oligonucleotides blocked noradrenaline activation of $\mathrm{OAG}$-sensitive cation channels [42]. On the other hand, the cholinergic stimulation of phospholipase $\mathrm{C}$ caused little or no activation of DAG-sensitive (putative TRP6) cation channels in PC12 cells [21]. In the case of stimulated T-lymphocytes, it is possible that DAG is formed at concentrations not sufficient to activate the DAG-sensitive channels, or that it is released far from the PM domains where the channels are located. However, we cannot exclude the possibility that agonists and signalling events, other than those explored here, can involve DAG-sensitive PM cation channels in $\mathrm{T}$-lymphocytes. Indeed, a variety of receptors (other than the ' $\mathrm{T}$ cell receptor') and co-receptors is known to be present on the T-cell surface. Moreover, $\mathrm{Ca}^{2+}$ signalling lasts for a very long time in stimulated lymphocytes [43], and different channels may be involved in the different phases. Alternatively, exogenously added DAG (and particularly OAG) may simply reveal the expression of cation channels of T-lymphocytes, whose physiological role needs further investigation.
We are grateful to Dr Tullio Pozzan for helpful discussion. This work was supported by grants from the following: Italian Ministry of Instruction, University and Scientific Research MIUR (Cofin 1999 to A. B.), University of Padova (Progetto di Ricerca di Ateneo 1999 to C. Fasolato and P.P.), University of Siena (Progetto Giovani Ricercatori to E.G.) and the Italian Space Agency ASI (to A.B.).

\section{REFERENCES}

1 Fasolato, C., Innocenti, B. and Pozzan, T. (1994) Receptor-activated $\mathrm{Ca}^{2+}$ influx: how many mechanisms for how many channels? Trends Pharmacol. Sci. 15, 77-83

2 Barritt, G. J. (1999) Receptor-activated $\mathrm{Ca}^{2+}$ inflow in animal cells: a variety of pathways tailored to meet different intracellular $\mathrm{Ca}^{2+}$ signalling requirements. Biochem. J. 337, 153-169

3 Putney, Jr, J. W. (1990) Capacitative calcium entry revisited. Cell Calcium 11, 611-624

4 Berridge, M. J. (1995) Capacitative calcium entry. Biochem. J. 312, 1-11

5 Hoth, M. and Penner, R. (1992) Depletion of intracellular calcium stores activates a calcium current in mast cell. Nature (London) 355, 353-356

6 Zweifach, A. and Lewis, R. S. (1993) Mitogen-regulated $\mathrm{Ca}^{2+}$ current of $\mathrm{T}$ lymphocytes is activated by depletion of intracellular $\mathrm{Ca}^{2+}$ stores. Proc. Natl. Acad. Sci. U.S.A. 90, 6295-6299

7 Parekh, A. B. and Penner, R. (1997) Store depletion and calcium influx. Physiol. Rev. 77, 901-930

8 Clapham, D. E., Runnels, L. W. and Strubing, C. (2001) The TRP ion channel family. Nat. Rev. Neurosci. 2, 387-396

9 McKay, R. R., Szymeczek-Seay, C. L., Lievremont, J. P., Bird, G. St. J., Zitt, C., Jüngling, E., Lückhoff, A. and Putney, Jr, J. W. (2000) Cloning and expression of the human transient receptor potential 4 (TRP4) gene: Iocalization and functional expression of human TRP4 and TRP3. Biochem. J. 351, 735-746

10 Hurst, R. S., Zhu, X., Boulay, G., Birnbaumer, L. and Stefani, E. (1998) Ionic currents underlying HTRP3 mediated agonist-dependent $\mathrm{Ca}^{2+}$ influx in stably transfected HEK293 cells. FEBS Lett. 422, 333-338

11 Zhu, X., Jiang, M., Peyton, M., Boulay, G., Hurst, R., Stefani, E. and Birnbaumer, L. (1996) trp, a novel mammalian gene family essential for agonist-activated capacitative $\mathrm{Ca}^{2+}$ entry. Cell 85, 661-671

12 Liu, X., Wang, W., Singh, B. B., Lockwich, T., Jadlowiec, J., O' Connel, B., Wellner, R., Zhu, M. X. and Ambudkar, I. S. (2000) Trp1, a candidate protein for the storeoperated $\mathrm{Ca}^{2+}$ influx mechanism in salivary gland cells. J. Biol. Chem. 275, 3403-3411

13 Zhu, X., Jiang, M. and Birnbaumer, L. (1998) Receptor-activated $\mathrm{Ca}^{2+}$ influx via human Trp3 stably expressed in human embryonic kidney (HEK)293 cells. Evidence for a non-capacitative activated $\mathrm{Ca}^{2+}$ entry. J. Biol. Chem. 273, 133-142

14 Strotmann, R., Harteneck, C., Nunnenmacher, K., Schultz, G. and Plant, T. D. (2000) OTRPC4, a nonselective cation channel that confers sensitivity to extracellular osmolarity. Nat. Cell Biol. 2, 695-702

15 Hofmann, T., Obukhov, A. G., Schaefer, M., Harteneck, C., Gudermann, T. and Schultz, G. (1999) Direct activation of human TRPC6 and TRPC3 channels by diacylglycerol. Nature (London) 397, 259-263

16 Ma, H. T., Patterson, R. L., van Rossum, D. B., Birnbaumer, L., Mikoshiba, K. and Gill, D. L. (2000) Requirement of the inositol trisphosphate receptor for activation of store-operated $\mathrm{Ca}^{2+}$ channels. Science 287, 1647-1651

17 Okada, T., Inoue, R., Yamazaki, K., Maeda, A., Kurosaki, T., Yamakuni, T., Tanaka, I., Shimizu, S., Ikenaka, K., Imoto, K. and Mori, Y. (1999) Molecular and functional characterization of a novel mouse transient receptor potential protein homologue TRP7. J. Biol. Chem. 274, 27359-27370

18 Zhang, L. and Saffen, D. (2001) Muscarinic acetylcholine receptor regulation of TRP-6 $\mathrm{Ca}^{2+}$ channel isoforms: molecular structures and functional characterization. J. Biol. Chem. 276, 13331-13339

19 Helliwell, R. M. and Large, W. A. (1997) $\alpha_{1}$-Adrenoceptor activation of a non-selective cation current in rabbit portal vein by 1,2-diacyl-sn-glycerol. J. Physiol. $\mathbf{4 9 9}$, $417-428$

20 Su, Z., Csutora, P., Hunton, D., Shoemaker, R. L., Marchase, R. B. and Blalock, J. E. (2001) A store-operated nonselective cation channel in lymphocytes is activated directly by $\mathrm{Ca}^{2+}$ influx factor and diacylglycerol. Am. J. Physiol. 280, C1284-C1292

21 Tesfai, T., Brereton, H. M. and Barritt, G. J. (2001) A diacylglycerol-activated $\mathrm{Ca}^{2+}$ channel in PC12 cells (an adrenal chromaffin cell line) correlates with expression of the TRP-6 (transient receptor potential) protein. Biochem. J. 358, 717-726

22 Wack, A., Soldaini, E., Tseng, C., Nuti, S., Klimpel, G. and Abrignani, S. (2001) Binding of the hepatitis $C$ virus envelope protein E2 to CD81 provides a costimulatory signal for human T cells. Eur. J. Immunol. 31, 166-175

23 Malgaroli, A., Milani, D., Meldolesi, J. and Pozzan, T. (1987) Fura-2 measurement of cytosolic free $\mathrm{Ca}^{2+}$ in monolayers and suspensions of various types of animal cells. J. Cell Biol. 105, 2145-2155 
24 DiVirgilio, F., Fasolato, C. and Steinberg, T. H. (1988) Inhibitors of membrane transport system anions block fura-2 excretion from PC12 and N2A cells Biochem. J. 256, 959-963

25 Grynkiewicz, G., Poenie, M. and Tsien, R. Y. (1985) A new generation of $\mathrm{Ca}^{2+}$ indicators with greatly improved fluorescence properties. J. Biol. Chem. 260 , $3440-3450$

26 Gamberucci, A., Fulceri, R., Marcolongo, P., Pralong, W.-F. and Benedetti, A. (1998) Histones and basic polypeptides activate $\mathrm{Ca}^{2+} /$ cation influx in various cell types. Biochem. J. 331, 623-630

27 Pizzo, P., Burgo, A., Pozzan, T. and Fasolato, C. (2001) Role of capacitative calcium entry on glutamate-induced calcium influx in type-I rat cortical astrocytes. J. Neurochem. 79, 98-109

28 Chaney, L. K. and Jacobson, B. S. (1983) Coating cells with colloidal silica for high yeld isolation of plasma membrane sheets and identification of transmembrane proteins. J. Biol. Chem. 258, 10062-10072

29 Jacobson, B. S., Schnitzer, J. E., McCaffery, M. and Palade, G. E. (1992) Isolation and partial characterization of the luminal plasmalemma of microvascular endothelium from rat lungs. Eur. J. Cell Biol. 58, 296-306

30 Haverstick, D. M., Dicus, M., Resnick, M. S., Sando, J. J. and Gray, L. S. (1997) A role for protein kinase $\mathrm{C} \beta$ 1 in the regulation of $\mathrm{Ca}^{2+}$ entry in Jurkat T cells. J. Biol. Chem. 272, 15426-15433

31 Straus, D. B. and Weiss, A. (1992) Genetic evidence for the involvement of the Ick tyrosine kinase in signal transduction through the T cell antigen receptor. Cell $\mathbf{7 0}$, 585-593

32 Cahalan, M. D., Wulff, H. and Chandy, K. G. (2001) Molecular properties and physiological roles of ion channels in the immune system. J. Clin. Immunol. 21, 235-252

33 Latorre, R., Oberhauser, A., Labarca, P. and Alvarez, O. (1989) Varieties of calciumactivated potassium channels. Annu. Rev. Physiol. 51, 385-399

Received 7 November 2001/25 January 2002; accepted 26 February 2002
34 Fomina, A. F., Fanger, C. M., Kozak, J. A. and Cahalan, M. D. (2000) Single channel properties and regulated expression of $\mathrm{Ca}^{2+}$ release-activated $\mathrm{Ca}^{2+}$ (CRAC) channels in human T cells. J. Cell. Biol. 150, 1435-1444

35 Mason, M. J., Mayer, B. and Hymel, L. J. (1993) Inhibition of $\mathrm{Ca}^{2+}$ transport pathways in thymic lymphocytes by econazole, miconazole, and SKF 6365 Am. J. Physiol. 264, C654-C662

36 Putney, Jr, J. W. (2001) Pharmacology of capacitative calcium entry. Mol. Interv. 1, 84-94

37 Ma, H. T., Venkatachalam, K., Li, H. S., Montell, C., Kurosaki, T., Patterson, R. L. and Gill, D. L. (2001) Assessment of the role of the inositol 1,4,5-trisphosphate receptor in the activation of transient receptor potential channels and store-operated $\mathrm{Ca}^{2+}$ entry channels. J. Biol. Chem. 276, 18888-18896

38 Gamberucci, A., Innocenti, B., Fulceri, R., Bànhegyi, G., Giunti, R., Pozzan, T. and Benedetti, A. (1994) Modulation of $\mathrm{Ca}^{2+}$ influx dependent on store depletion by intracellular adenine-guanine nucleotide levels. J. Biol. Chem. 269, 23597-23602

39 Gilabert, J. A., Bakowski, D. and Parekh, A. B. (2001) Energized mitochondria increase the dynamic range over which inositol 1,4,5-trisphosphate activates storeoperated calcium influx. EMBO J. 20, 2672-2679

40 Zhang, Z., Tang, J., Tikunova, S., Johnson, J. D., Chen, Z., Qin, N., Dietrich, A., Stefani, E., Birnbaumer, L. and Zhu, M. X. (1998) Activation of Trp3 by inositol 1,4,5trisphosphate receptors through displacement of inhibitory calmodulin from a common binding domain. Proc. Nat. Acad. Sci. U.S.A. 98, 3168-3173

41 Patterson, R. L., van Rossum, D. B. and Gill, D. L. (1999) Store-operated Ca ${ }^{2+}$ entry: evidence for a secretion-like coupling model. Cell 98, 487-499

42 Inoue, R., Okada, T., Onoue, H., Hara, Y., Shimizu, S., Naitoh, S., Ito, Y. and Mori, Y. (2001) The transient receptor potential protein homologue TRP6 is the essential component of vascular $\alpha_{1}$-adrenoceptor-activated $\mathrm{Ca}^{2+}$-permeable cation channel. Circ. Res. 88, 325-332

43 Lewis, S. R. (2001) Calcium signaling mechanisms in T lymphocytes. Annu. Rev. Immunol. 19, 497-521 